\title{
COVID-19 phobia in healthcare workers; a cross-sectional study from a pandemic hospital
}

\author{
Burcu OKTAY \\ $\operatorname{ARSLAN}^{1}$ (ID) \\ Özgür BATUM ${ }^{1}$ (ID) \\ Yelda $\operatorname{VAROL}^{1}($ ID) \\ Emre ŞENEL $^{2}$ (ID) \\ Zeynep Zeren $\mathrm{UÇAR}^{1}$ (ID)
}

\author{
${ }^{1}$ Clinic of Chest Diseases University of Health Sciences, Dr. Suat Seren Chest \\ Diseases and Chest Surgery Training and Research Hospital, Izmir, Turkey \\ ${ }^{1}$ Sağlık Bilimleri Üniversitesi Dr. Suat Seren Göğüs Hastalıkları ve Cerrahisi \\ Ĕgitim ve Araştırma Hastanesi, Göğüs Hastalıkları Kliniği, İzmir, Türkiye \\ ${ }^{2}$ Clinic of Intensive Care Unit, University of Health Sciences, \\ Dr. Suat Seren Chest Diseases and Chest Surgery Training and \\ Research Hospital, Izmir, Turkey \\ ${ }^{2}$ Sağlık Bilimleri Üniversitesi Dr. Suat Seren Göğ̈̈s Hastalıkları ve Cerrahisi \\ Ĕgitim ve Araştırma Hastanesi, Yoğun Bakım Kliniği, İzmir, Türkiye
}

Cite this article as: Oktay Arslan B, Batum Ö, Varol Y, Şenel E, Uçar ZZ. COVID-19 phobia in healthcare workers; a cross-sectional study from a pandemic hospital. Tuberk Toraks 2021;69(2):207-216.

Yazışma Adresi (Address for Correspondence)

\section{Dr. Burcu OKTAY ARSLAN}

Sağlık Bilimleri Üniversitesi Dr. Suat Seren Göğüs Hastalıkları ve Cerrahisi Eğitim ve Araştırma Hastanesi, Göğüs Hastalıkları Kliniği, IZMIR - TÜRKIYE

e-mail: dr.arslanburcu@gmail.com

CCopyright 2021 by Tuberculosis and Thorax.

Available on-line at www.tuberktoraks.org.com

\section{ABSTRACT \\ COVID-19 phobia in healthcare workers; a cross-sectional study from a pandemic hospital}

Introduction: Healthcare workers (HCWs) are at the forefront of the fight against coronavirus. The purpose of this study was to evaluate COVID-19 phobia levels of HCWs of a pandemic hospital and explore associated factors.

Materials and Methods: This was a descriptive cross-sectional study conducted on HCWs employed in a pandemic hospital. A total of 365 HCWs (95 physicians, 187 nurses and 83 assistant healthcare staffs) were included in the study. In order to evaluate COVID-19 phobia, coronavirus-19 phobia scale (C19P-S) was administrated. Chronophobia levels of frontline and nonfrontline HCWs were compared. Additionally, the effect of working in different departments, profession and associated factors on COVID-19 phobia was evaluated.

Results: Overall, 172 HCWs completed the C19P-S and agreed to participate in the study. Mean total CP19P-S score of the HCWs included in the study was $50.1 \pm 17.3$. Of the study population, $59.3 \%$ participants were frontline HCWs and $40.7 \%$ were non-frontline HCWs. When frontline HCWs and nonfrontline HCWs were compared in terms of total C19P-S and subscales scores (psychological, psycho-somatic, economic, social), no statistically significant differences were found ( $p=0.914, p=0.687, p=0.766, p=0.347, p=0.794$, respectively). When the HCWs were divided into three groups according to departments (clinics, intensive care unit (ICU), emergency department) where they worked regardless of whether they cared for patients with COVID-19, HCWs employed in the ICUs had the highest scores regarding total C19P-S and subscales scores $(p=0.002, p=0.001, p=0.001, p=0.012$, 
$p=0.002$, respectively). Profession based comparison revealed no significant difference between the groups regarding total C19P-S score $(p=0.117)$.

Conclusion: It is essential to make a comprehensive evaluation regarding the effects of pandemics on HCWs, not only for controlling the COVID-19 pandemic but also to protect the mental health of HCWs. Critical care professions appear to need particular attention among HCWs. The C19P-S, which assesses coronaphobia levels with psychological, psycho-somatic, economic, and social aspects could be a convenient screening tool for evaluating COVID-19 phobia levels in HWCs.

Key words: COVID-19; health care workers; chronophobia; coronavirus-19 phobia scale

\section{ÖZ}

\section{Sağlık çalışanlarında COVID-19 fobisi; bir pandemi hastanesinden kesitsel bir çalışma}

Giriş: Sağılk çalışanları koronavirüsle mücadelede en ön saflarda yer almaktadırlar. Bu çalışmanın amacı, bir pandemi hastanesinde görev yapan sağlık çalışanlarının COVID-19 fobi düzeylerini değerlendirmek ve ilgili faktörleri araştırmaktır.

Materyal ve Metod: Bu çalışma, bir pandemi hastanesinde görev yapmakta olan sağlık çalışanları üzerinde gerçekleştirilen tanımlayıcı kesitsel bir çalışmadır. Çalışmaya 365 sağlık çalışanı (95 doktor, 187 hemşire ve 83 yardımcı sağlık personeli) dahil edilmiştir. COVID-19 fobisini değerlendirmek için koronavirüs-19 fobi ölçeği (C19P-S) uygulanmıştır. Ön saflarda görev alan ve almayan sağlık çalışanlarının koronofobi seviyeleri karşılaştırılmıştır. Ayrıca farklı departmanlarda, mesleklerde çalışmanın ve ilişkili faktörlerin COVID-19 fobisi üzerindeki etkisi değerlendirilmiştir.

Bulgular: Toplamda 172 sağlık çalışanı C19P-S tamamladı ve çalışmaya katılmayı kabul etti. Katılımcıların toplam C19P-S puanı 50,1 $\pm 17,3$ idi. Katılımcıların \%59,3'ü ön saflarda görev alan sağlık çalışanlarından ve 40.7'si ön saflarda görev olmayan sağlık çalışanlarından oluşmaktaydı. Ön saflarda görev alan ve almayan sağlık çalışanları toplam C19P-S ve alt ölçek puanları (psikolojik, psiko-somatik, ekonomik, sosyal) açısından karşılaştırıldığında istatistiksel olarak anlamlı bir farklılık bulunmamıştır $(p=0,914, p=0,687, p=$ $0,766, p=0,347, p=0,794$, sırasıyla). Sağılk çalışanları, COVID-19 hastaları ile çalışıp çalışmadıklarına bakılmaksızın, bölümlere göre (servis, yoğun bakım ünitesi (YBÜ), acil servis) gruplandırıldıklarında, YBÜ'de görev yapan sağlık çalışanlarının toplam C19P-S ve alt ölçek puanları (psikolojik, psiko-somatik, ekonomik, sosyal) yönünden en yüksek değerlere sahip oldukları belirlenmiştir ( $p=0,002$, $p=0,001, p=0,001, p=0,001, p=0,012, p=0,002$ sırasıyla). Meslek temelli karşılaştırmada gruplar arasında C19P-S skoru açısından istatistiksel anlamlı farklılık tespit edilmemiştir $(p=0,117)$.

Sonuç: Yalnızca COVID-19 salgınını kontrol edebilmek için değil, aynı zamanda sağlık çalışanlarının ruh sağlığını korumak için de, salgının sağlık çalışanları üzerindeki etkilerini kapsamlı bir şekilde değerlendirmek oldukça önemlidir. Bu bağlamda yoğun bakım çalışanlarının, sağlık çalışanları arasında özel bir ilgiye ihtiyacı olduğu görülmektedir. Koronofobi düzeyini psikolojik, psiko-somatik, ekonomik ve sosyal yönleriyle değerlendiren C19P-S, bu amaca yönelik kullanılabilecek uygun bir tarama anketi olabilir.

Anahtar kelimeler: COVID-19; sağlık çalışanları; koronovirüs; koronavirüs-19 fobi ölçeği

\section{INTRODUCTION}

An epidemic of a novel coronavirus disease (SARSCoV-2) was first described in Wuhan, China, which spread throughout the world (1). On March $11^{\text {th }}$, 2020, the World Health Organization (WHO) declared COVID-19 as a global pandemic due to the rapid spread of the virus and continual rise in affected countries (2). On March $11^{\text {th }}, 2020$, Turkey also joined the affected countries, and the first case was announced (3). Currently, coronavirus is still spreading, and various measures have been taken to prevent the spread of the outbreak, including a global lockdown (4). A socially distant, masked, and homebased lifestyle had to be experienced by all humanity to protect itself, loved ones, and the rest of the world. Despite all of these measures and efforts, the pandemic and the number of infected patients is not under control. Furthermore, there is no particular estimation as to the duration of the pandemic, there is no proven antiviral curative treatment and COVID19 cases and mortality rates continue to rise $(5,6)$. The uncertainties about when the pandemic will end and the new lifestyle with numerous restrictions have detrimental effects at individual and societal levels $(6,7)$. The coronavirus is still affecting large populations in terms of health, psychology, social interaction, and economy $(4,8)$.

Healthcare workers (HCWs) are at the frontline of the COVID-19 pandemic defense and are subject to additional stress due to frequent exposure to infected individuals, increased risk for contagion, fear of transmission to their families, long working hours, fatigue, and psychological distress $(5,9)$. There are several studies reporting that the COVID-19 pandemic has increased the risk of mental disorders including anxiety, depression, and acute stress disorders among both healthcare professionals and the public (10-12). During epidemics, people usually experience various 
difficulties such as fear, panic, and phobia. It is important to identify COVID-19-related fear and phobia and provide psychological support to prevent more complicated disorders (13).

For this purpose, several measurement tools have been developed and validated to measure anxiety, fear, and phobia related to the COVID-19 pandemic (14-16). Arpacı et al. have developed a COVID-19 phobia scale (C19P-S), whose items correspond to the specific phobia diagnostic criteria of the Diagnostic and Statistical Manual of Mental Disorders, Fifth Edition (DSM-V) and proposed "coronaphobia" as a persistent and excessive fear of the novel coronavirus (17). The main characteristics of specific phobias are fear and anxiety limited by the phobia source (18). The COVID-19 pandemic disrupts people's routine and elicits anxiety and phobic reactions (17).

The purpose of this study was to evaluate COVID-19 phobia levels of HCWs of a pandemic hospital and explore associated factors.

\section{MATERIALS and METHODS}

\section{Design}

This was a descriptive cross-sectional study conducted on a group of HCWs of a chest medicine and chest surgery training and research hospital in Turkey. After the outbreak of the COVID-19 pandemic, the hospital was designated as a pandemic hospital. In addition to chest disease clinics and intensive care units (ICUs), COVID-19 clinics and COVID-19 ICUs started to open.

\section{Subjects}

The study population was composed of HCWs who worked in the department of chest diseases, COVID19 wards, ICUs and the emergency department of our hospital. A total of 95 physicians, 187 nurses, and 83 assistant healthcare staff were employed in these departments of the hospital. In order to evaluate the COVID-19 phobia of the HCWs, C19P-S was administered. The C19P-S was distributed to HCWs between August $1^{\text {st }}, 2020$, and August $15^{\text {th }}, 2020$, and the HCWs were asked to complete the scale. Each clinic was visited twice per week during this period. The completed forms were collected, and a reminder was sent to those who had not completed them. The demographic information of all HCWs who completed the C19P-S and agreed to participate in the study was also recorded.
We estimated coronavirus phobia and the fear of COVID-19 using the C19P-S among healthcare professionals. In the study, HCWs working in COVID wards and the COVID-19 ICU were regarded as frontline HCWs, and those not working in these departments were considered as non-frontline HCWs. The coronaphobia levels of frontline and non-frontline HCWs were compared. In addition, the effect of working in different departments, professions, and associated factors on COVID-19 phobia was evaluated.

\section{Coronavirus-19 Phobia Scale (C19P-S)}

The C19P-S was developed and validated as a self-report instrument with a 5-point Likert-type scale to assess the levels of coronavirus phobia (17). The C19P-S has 20 items with four factors: Psychological, Psycho-somatic, Economic, and Social. The $1^{\text {st }}, 5^{\text {th }}$, $9^{\text {th }}, 13^{\text {th }}, 17^{\text {th }}$, and $20^{\text {th }}$ items measure the psychological factor; the $2^{\text {nd }}, 6^{\text {th }}, 10^{\text {th }}, 14^{\text {th }}$, and $18^{\text {th }}$ items measure the somatic factor; the $3^{\text {rd }}, 7^{\text {th }}, 11^{\text {th }}, 15^{\text {th }}$, and $19^{\text {th }}$ measure the social factor; and the $4^{\text {th }}, 8^{\text {th }}$, $12^{\text {th }}$, and $16^{\text {th }}$ items measure the economic factor. The psychological factor includes items related to one's experiences of excessive anxiety and fear due to potential infection with coronavirus; the psycho-somatic factor includes items related to the physical symptoms associated with the phobia of coronavirus; the economic factor includes items related to hoarding behaviors due to the excessive fear of running out of supplies; and the social factor includes items gauging the extent to which one experiences social phobia due to COVID-19. All items are rated on a 5 -point scale from "strongly disagree (1)" to "strongly agree (5)." Sub-scale scores are obtained by the sum of points of the answers given to the items of that sub-scale; the total C19P-S score is obtained by the sum of the subscale scores and ranges from 20 to 100 points. A cut-off value for the level of coronaphobia has not yet been determined related to the C19P-S. A higher score indicates a greater phobia in the respected subscales and total scale $(13,17)$. Arpacı et al. have shown that the scale had promising reliability and validity properties, and C19P-S might be used to assess the severity of coronaphobia (17).

\section{Statistical Analysis}

The data were analyzed using the IBM-SPSS 25.0 package. Quantitative data were reported as mean \pm standard deviation (SD) or as median with minimum-maximum values, and qualitative data were 
reported as observed frequencies and percentages. The Shapiro-Wilk test was used to check normality and according to the results parametric or non-parametric suitable statistical tests were performed. Mann-Whitney $U$ test was used for comparison between independent groups for values that were not normally distributed. An independent samples t-test was used to compare two groups for values that were normally distributed. Analysis of variance (ANOVA) or the Kruskal-Wallis test was used for comparisons of more than two groups. If ANOVA was significant, the Bonferroni test was used for paired comparisons.

A Chi-square test was used to assess associations between qualitative variables. The level of significance was set at 0.05 .

All procedures performed in the studies involving human participants were in accordance with the ethical standards of the institutional and/or national research committee and with the 1964 Helsinki declaration (as revised in Edinburgh 2013) and its later amendments or comparable ethical standards. Informed consent was obtained from all individual participants included in the study. The study was approved by the local research ethics committee (The study was approved by the University of Health Science, Dr. Suat Seren Chest Disease and Chest Surgery Training and Research Hospital Date: 22.07.2020, Number: 18.

\section{RESULTS}

A total of $191 \mathrm{HCW}$ s responded. Response rate was $52.3 \%$. Nineteen respondents were excluded from the study due to missing information; overall, 172 HCWs were included in the study. Mean age of the study population was $34.8 \pm 8.7$ years and $25.6 \%$ of those were males. Of the participants, $24.4 \%$ were physicians, $42.4 \%$ were nurses, and $33.1 \%$ were assistant health staff. In the group, $11.6 \%$ of the participants had at least one co-morbidity. Table 1 demonstrates the sociodemographic characteristics and the CP19P-S scores of the study population.

Mean total C19P-S score of the HCWs included in the study was $50.1 \pm 17.3$. Figure 1 demonstrates the psychological, psycho-somatic, economic, and social scores of the participants. When the total C19P-S scores of HCWs were compared between males and females, smokers and non-smokers, married and single participants, those with or without children, and those with or without chronic illness, no significant differences were found $(p=0.146, p=0.481, p=$ $0.476, p=0.401, p=0.724$, respectively). In order to examine the effects of age intervals on C19P-S, we created 10-year intervals. Our results demonstrated no significant differences among the age groups regarding total C19P-S scores $(p=0.416)$.

Of the study population, 102 participants were frontline HCWs and 70 were non-frontline HCWs. There was a statistically significant difference between these two groups regarding age, year of experience in the profession, and having children $(p=0.001, p=$ $0.001, p=0.025$, respectively). When the frontline $\mathrm{HCW}$ s and non-frontline HCWs were compared in terms of total C19P-S and subscales scores, no statistical differences were found $(p=0.914, p=0.687, p=$ $0.766, p=0.347, p=0.794$, respectively) (Table 2 ).

When the participants of the study were divided into three groups according to the departments where they worked, regardless of whether they cared for patients with COVID-19, statistically significant differences were found between the groups concerning psychological, psycho-somatic, economic, social, and total C19P-S scores $(p=0.001, p=0.001, p=$ $0.012, p=0.002, p=0.002$ ). HCWs employed in the ICUs had the highest scores at all parameters (Table 3). In pairwise group comparisons, it was found that the statistical significance continued between HCWs who worked in the clinics and ICUs regarding total C19P-S scores, psychological scores, economic scores, and social scores $(p=0.001, p=0.001, p=$ $0.002, p=0.01$, respectively). In terms of somatic scores, pairwise group comparisons showed differences between HCWs who worked in the clinics and ICUs, and ICUs and the emergency department $(p=$ $0.002, p=0.024$, respectively).

When the participants were grouped based on their professions as physicians, nurses, and assistant healthcare staffs, no significant difference was found regarding total C19P-S and subscales scores (Table 4).

\section{DISCUSSION}

The present study investigated the coronaphobia levels of the HCWs of a pandemic hospital. Although no cut-off was determined because higher scores indicate greater phobia, our results could be interpreted as that the HCWs had moderate coronaphobia levels. The current study demonstrated that there was no difference between frontline HCWs and non-frontline HCWs regarding COVID-19-related phobia. 
Table 1. Demographic features and the C19P-S score of the entire study population ( $n=172$ )

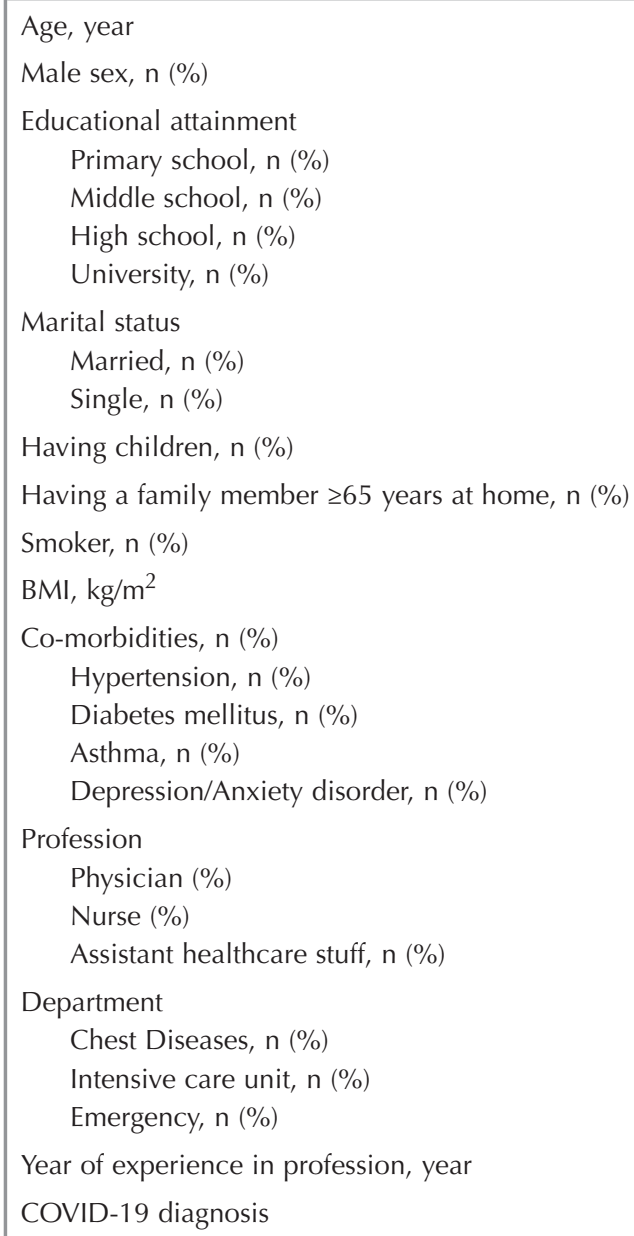

BMI: Body mass index, C19P-S: COVID-19 phobia scale.

Data is depicted as mean $\pm \mathrm{SD}$, median (min-max) or number (percentage).

However, HCWs employed in the ICUs had the highest levels of coronaphobia in both total and the psychological, psycho-somatic, economic, and social aspects. It is essential to evaluate the well-being status and mental health of HCWs to prevent more complicated disorders and to fight against pandemics such as COVID-19. To our knowledge, this is the first study to examine the coronaphobia levels of HCWs using C19P-S.

Many things have changed since the COVID-19 pandemic entered our lives. Healthcare professionals, perhaps the group that felt this change most intensely, had to work harder with an intense workload and psychological pressure during the pandemic, and still, they continue. Healthcare professionals have been exposed to a high risk of contamination and infection, overwork, frustration, and isolation (19). Fear of transmitting the infection to loved ones, having to separate from family members during the pandemic, uncertainty about the course of the pandemic, and the scarcity of available knowledge should also be added to the list of difficulties that HWCs had 


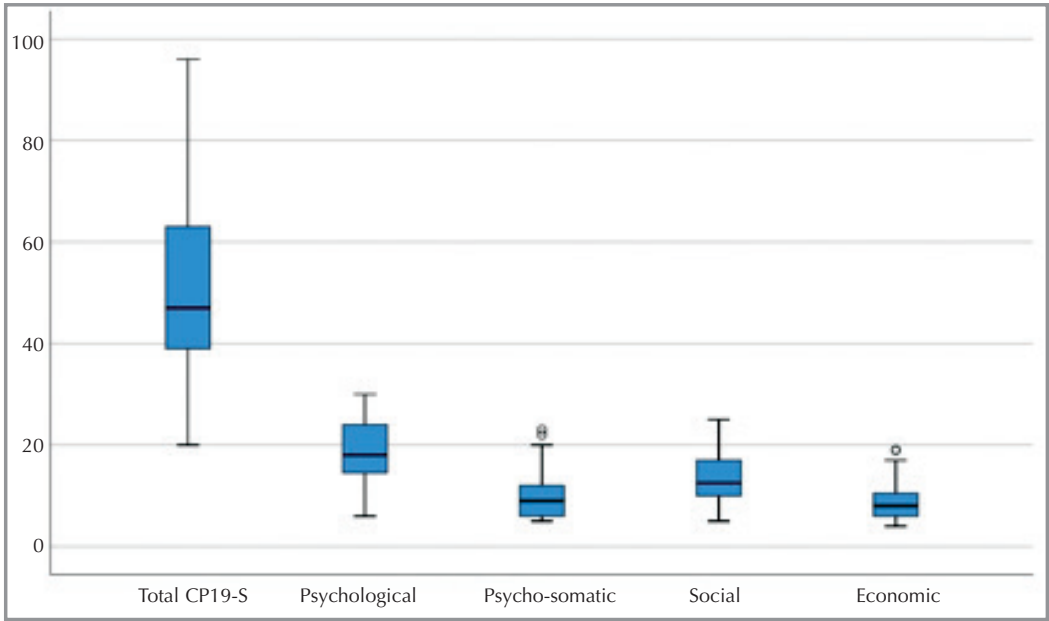

Figure 1. Total and subscale scores of C19P-S of study population.

C19P-S: COVID-19 phobia scale.

Table 2. Comparison of frontline and non-frontline HCWs regarding demographic features and C19P-S scores

\begin{tabular}{|c|c|c|c|}
\hline & $\begin{array}{c}\text { Frontline HCWs } \\
\quad(n=102)\end{array}$ & $\begin{array}{l}\text { Non-frontline HCWs } \\
(n=70)\end{array}$ & $\mathbf{p}$ \\
\hline Age, year & $32.9 \pm 7.5$ & $37.5 \pm 9.6$ & 0.001 \\
\hline Male sex, n (\%) & $27(26.5)$ & $17(24.3)$ & 0.747 \\
\hline $\mathrm{BMI}, \mathrm{kg} / \mathrm{m}^{2}$ & $24.4 \pm 3.2$ & $24.3 \pm 3.2$ & 0.649 \\
\hline Smoker, n (\%) & $31(30.4)$ & $26(37.1)$ & 0.355 \\
\hline Marital status (married), n (\%) & $65(63.7)$ & $46(65.7)$ & 0.789 \\
\hline Having children, $\mathrm{n}(\%)$ & $42(41.2)$ & $41(58.6)$ & 0.025 \\
\hline Having a family member $\geq 65$ years at home, $\mathrm{n}(\%)$ & $9(8.8)$ & $7(10)$ & 0.794 \\
\hline Co-morbidities, n (\%) & $10(9.8)$ & $10(14.3)$ & 0.368 \\
\hline Diagnosis of depression and/or anxiety disorder, $\mathrm{n}(\%)$ & $6(5.9)$ & $6(8.6)$ & 0.551 \\
\hline Diagnosis of COVID-19 & $1(1.4)$ & $2(2.8)$ & 0.793 \\
\hline Year of experience in profession, year & $8(1-33)$ & $14(1-38)$ & 0.001 \\
\hline Psychological score & $18.5 \pm 6.4$ & $18.8 \pm 6.1$ & 0.687 \\
\hline Psycho-somatic score & $9.6 \pm 3.9$ & $9.4 \pm 4.2$ & 0.766 \\
\hline Economic score & $8.6 \pm 3.2$ & $8.1 \pm 3.4$ & 0.347 \\
\hline Social score & $13.3 \pm 5.1$ & $13.4 \pm 5.2$ & 0.794 \\
\hline Total C19P-S score & $50.3 \pm 17$ & $50.01 \pm 17.5$ & 0.914 \\
\hline
\end{tabular}

to deal with $(4,20)$. All these severe situations cause psychological consequences. In the COVID-19 pandemic, as in other pandemics, worries, anxiety, and fear have been reported as the major psychological consequences (21).

Researchers have used the expressions "fear of COVID-19" and "coronaphobia" to manifest the fear of contracting COVID-19 (21). Coronaphobia is still in the early phase of development. Research on coronaphobia has revealed that it is strongly associated with elevated depression, anxiety, hopelessness, and functional impairments (22). Arpaci et al. have developed the C19P-S and proposed coronaphobia as a particular type of DSM-V specific phobia. They revealed that the C19P-S items provided support for 
Table 3. Comparison of sociodemographic characteristics and C19P-S scores of the HCWs according to the departments where they worked

\begin{tabular}{|c|c|c|c|c|}
\hline & $\begin{array}{c}\text { Clinics (both chest } \\
\text { disease and COVID-19) } \\
(n=124)\end{array}$ & $\begin{array}{l}\text { Intensive Care Units } \\
\text { (both COVID-19 and non- } \\
\text { COVID-19) }(\mathrm{n}=38)\end{array}$ & $\begin{array}{l}\text { Emergency department } \\
\qquad(n=10)\end{array}$ & $\mathbf{p}$ \\
\hline Age, year & $35.5 \pm 9.2$ & $32.7 \pm 6.4$ & $33.8 \pm 8.4$ & 0.216 \\
\hline Male sex, n (\%) & $26(21)$ & $15(39.5)$ & $3(30)$ & 0.069 \\
\hline Smoker, n (\%) & $46(37.1)$ & $9(23.7)$ & $2(20)$ & 0.203 \\
\hline Marital status (married), n (\%) & $82(66.1)$ & $23(60.5)$ & $6(60)$ & 0.781 \\
\hline Having children, n (\%) & $59(47.6)$ & $17(44.7)$ & $7(70)$ & 0.349 \\
\hline $\begin{array}{l}\text { Having a family member } \geq 65 \\
\text { years at home, } n(\%)\end{array}$ & $9(7.3)$ & $5(13.2)$ & $2(20)$ & 0.267 \\
\hline Co-morbidities, n (\%) & $16(12.9)$ & $4(10.5)$ & $0(0)$ & 0.459 \\
\hline $\begin{array}{l}\text { Diagnosis of depression and/or } \\
\text { anxiety disorder, } \mathrm{n}(\%)\end{array}$ & $8(6.5)$ & $3(7.9)$ & $1(10)$ & 0.886 \\
\hline Diagnosis of COVID-19 & $2(1.6)$ & $1(2.6)$ & $0(0)$ & 0.833 \\
\hline $\begin{array}{l}\text { Year of experience in profession, } \\
\text { year }\end{array}$ & $10(1-38)$ & $9(1-27)$ & $13(1-23)$ & 0.812 \\
\hline Psychological score & $18(6-30)$ & $23(9-30)$ & $19(3-29)$ & 0.001 \\
\hline Psycho-somatic score & $8.5(5-23)$ & $11(5-20)$ & $8(5-16)$ & 0.001 \\
\hline Economic score & $8(4-19)$ & $10(4-19)$ & $8(5-14)$ & 0.012 \\
\hline Social score & $12(5-25)$ & $16(5-24)$ & $11(9-17)$ & 0.002 \\
\hline Total C19P-S score & $44(20-96)$ & $62(26-83)$ & $44.5(36-73)$ & 0.002 \\
\hline
\end{tabular}

Table 4. Comparison of C19P-S scores of physicians, nurses, and assistant healthcare staff

\begin{tabular}{|c|c|c|c|c|}
\hline & Physicians $(n=42)$ & Nurses $(n=73)$ & $\begin{array}{l}\text { Assistant healthcare staff } \\
\qquad(n=57)\end{array}$ & $\mathbf{p}$ \\
\hline Psychological score & $17.4 \pm 5.7$ & $19.5 \pm 6.0$ & $18.6 \pm 6.8$ & 0.224 \\
\hline Psycho-somatic score & $7.5(5-15)$ & $9(5-20)$ & $10(5-23)$ & 0.119 \\
\hline Economic score & $7(4-13)$ & $8(4-19)$ & $8(4-19)$ & 0.061 \\
\hline Social score & $11(5-24)$ & $13(5-25)$ & $13(5-25)$ & 0.200 \\
\hline Total C19P-S score & $45.5 \pm 14.0$ & $52.4 \pm 17.2$ & $50.3 \pm 19.0$ & 0.117 \\
\hline
\end{tabular}

assessing the levels of phobic reactions (17). In another study, the C19P-S has been adapted for the United States and used to examine the participant's characteristics regarding coronaphobia levels. The results of the study have indicated a significant positive correlation between coronaphobia and state anxiety. Additionally, the authors have also demonstrated that women experienced higher levels of coronaphobia, but only on its psychological aspects compare with men (13). Sex-based comparison of our study revealed no difference between the groups regarding psychological, psycho-somatic, economic, social aspects of coronaphobia.

Previous studies evaluating COVID-19-related fear have reported conflicting results. Andrade et al. and Haktanir et al. have demonstrated that women displayed more extensive fear compared with men, whereas Ahorsu et al. have found no sex differences $(6,14,23)$. We also investigated the effects of co-morbidities, smoking, marital status, having children, and 
age on the level of coronaphobia among HCWs and observed no effects. Arpaci et al. have also evaluated coronaphobia levels based on chronic disease and marital status and revealed similar results to the present study (13). Contrary to our results, Amin et al. have studied a group of frontline HCWs and reported that having children and younger age were associated with anxiety and depression (24).

The frontline HCWs of the present study were younger and had less work experience compared with the non-frontline HCWs. Additionally, the ratio of having children was higher among frontline HCWs than in the non-frontline HCWs. However, we determined no significant difference regarding coronaphobia levels of frontline and non-frontline HCWs. It is a fact that frontline HCWs are at increased risk of becoming infected with coronavirus (25). In a study from China, the average values of fear, anxiety, and depression due to COVID-19 pandemic have been reported higher in medical staff than in administrative staff (26). Another study from Saudi Arabia has revealed that HCWs in direct contact with patients with COVID-19 had significantly higher concern scores than those who were not (27). Similarly, anxiety was significantly higher in frontline HCWs compared with non-frontline HCWs (28). Contrary to these results, in the present study, both frontline and non-frontline HCWs demonstrated similar levels of coronaphobia. On the other hand, it was determined that, regardless of whether the HCWs cared for patients with COVID-19, ICU staff had the highest levels of coronaphobia in all aspects. Critical care professionals are vulnerable to mental health problems during outbreaks such as COVID-19 because of the constant fear and the demanding workload (29). Beyond the pandemic, critical care professionals are exposed to serious stressors including moral and spiritual distress related to ethical issues, uncertainty about patients' treatment, and a high risk of developing negative emotional responses due to exposure to sick and dying patients (30).

In terms of the impact on different health profession, Kramer et al. have reported that nurses experienced more stress than physicians during the COVID-19 pandemic (31). In this context, similar results have been demonstrated by researchers (28). However, Korkmaz et al. have determined no significant difference between different professions among HCWs regarding anxiety levels (32). Alternative findings have been observed by Liu et al. who reported the physicians had more stress and anxiety compared with nurses (19). In terms of coronaphobia levels, we observed no differences between physicians, nurses, and assistant healthcare staff.

This study has some limitations that must be addressed. First, the response rate was low. This might be attributed to the HCWs being tired and feeling exhausted due to the pandemic. We used a self-reported questionnaire to evaluate the coronaphobia levels of the HCWs, which may be affected by recall bias. Furthermore, the voluntary nature of the study might have led to selection bias. We could not make any comparisons with previous literature because C19P-S was used for the first time on HCWs. The absence of a determined cut-off value for the scale makes it difficult to interpret the severity of coronaphobia. Classification analysis should be conducted to evidence the classification power of the C19P-S (17). Additionally, the cross-sectional design of the study limited our ability to evaluate the effect of time on coronaphobia levels. At the time of administering the survey to the participants at the beginning of August, it was a period when the restrictions were reduced in Turkey.

\section{CONCLUSION}

It is essential to make a comprehensive evaluation regarding the effects of pandemics on HCWs, not only for controlling the COVID-19 pandemic but also to protect the mental health of HCWs. In order to provide psychological support and prevent more complicated disorders, COVID-19-related fear and phobia should be identified. Critical care professions appear to need particular attention among HCWs. The C19P-S, which assesses coronaphobia levels with psychological, psycho-somatic, economic, social aspects, could be a convenient screening tool for evaluating COVID-19 phobia levels in HWCs and preventing associated disorders. Further studies are required to validate this approach.

\section{Acknowledgement}

The authors thank to Dr. Suat Seren Chest Diseases and Chest Surgery Training and Research Hospital COVID-19 study group.

Ethical Committee Approval: The study was approved by the local research ethics committee (University of Health Science, Dr.Suat Seren Chest Disease and Chest Surgery Training and Research Hospital, Date: 22.07.2020, Number: 18). 


\section{CONFLICT of INTEREST}

The authors of this meta-analysis declare that they have no conflict of interest.

\section{AUTHORSHIP CONTRIBUTIONS}

\section{Concept/Design: BOA, ÖB, YV, ES}

Analysis/Interpretation: BOA, ÖB

Data Acqusition: BOA, ÖB, YV, EŞ

Writing: $\mathrm{BOA}, \mathrm{ZZU}$

Clinical Revision: BOA, ÖB, TV, ZZU

Final Approval: BOA, ÖB, YV, EŞ, ZZU

\section{REFERENCES}

1. Wan H, Cui JA, Yang GJ. Risk estimation and prediction of the transmission of coronavirus disease-2019 (COVID-19) in the mainland of China excluding Hubei province. Infect Dis Poverty 2020; 9(1): 116.

2. World Health Organization (WHO). WHO DirectorGeneral's remarks at the media briefing on 2019-nCoV on 11 February 2020.

3. Republic of Turkey, Ministry of Health. Türkiye Günlük Koronavirüs Tablosu. 2020. Available from: https:// covid19.saglik.gov.tr

4. Dubey S, Biswas P, Ghosh R, Chatterjee S, Dubey MI, Chatterjee S, et al. Psychosocial impact of COVID-19. Diabetes Metab Syndr 2020; 14(5): 779-88.

5. Abdel Wahed WY, Hefzy EM, Ahmed MI, Hamed NS. Assessment of Knowledge, Attitudes, and Perception of Health Care Workers Regarding COVID-19, a cross-sectional study from Egypt. I Community Health 2020; 45(6): 1242-51.

6. Haktanir A, Seki T, Dilmaç B. Adaptation and evaluation of Turkish version of the fear of COVID-19 Scale. Death Stud 2020:1-9.

7. Luchetti M, Lee JH, Aschwanden D, Sesker A, Strickhouser $J E$, Terracciano $A$, et al. The trajectory of loneliness in response to COVID-19. Am Psychol 2020; 75(7): 897-908.

8. Sarkodie SA, Owusu PA. Global assessment of environment, health and economic impact of the novel coronavirus (COVID-19). Environ Dev Sustain 2020:1-11.

9. Elbay RY, Kurtulmuş A, Arpacıoğlu S, Karadere E. Depression, anxiety, stress levels of physicians and associated factors in Covid-19 pandemics. Psychiatry Res 2020; 290: 113130 .

10. Qiu J, Shen B, Zhao M, Wang Z, Xie B, Xu Y. A nationwide survey of psychological distress among Chinese people in the COVID-19 epidemic: implications and policy recommendations. Gen Psychiatr 2020; 33(2): e100213.

11. Liang Y, Liang J, Zhou Q, Li X, Lin F, Deng Z, et al. Prevalence and clinical features of 2019 novel Coronavirus disease (COVID-19) in the Fever Clinic of a teaching hospital in Beijing: a single-center, retrospectivestudy. medRxiv 2020.
12. Lai I, Ma S, Wang Y, Cai Z, Hu J, Wei N, et al. Factors associated with mental health outcomes among health care workers exposed to coronavirus disease 2019. JAMA Netw Open 2020; 3(3): e203976.

13. Arpaci I, Karatas K, Balog/u M, Haktanir A. COVID-19 phobia in the United States: validation of the COVID-19 phobia scale (C19P-SE). Death Stud 2021:1-7.

14. Ahorsu $D K$, Lin $C Y$, Imani $V$, Saffari $M$, Griffiths $M D$, Pakpour AH. The fear of COVID-19 scale: development and initial validation. Int J Ment Health Addict 2020:1-9.

15. Lee SA. Coronavirus anxiety scale: a brief mental health screener for COVID-19 related anxiety. Death Stud 2020; 44(7): 393-401.

16. Taylor S, Landry CA, Paluszek MM, Fergus TA, McKay D, Asmundson GJG. Development and initial validation of the COVID stress scales. I Anxiety Disord 2020; 72: 102232.

17. Arpaci I, Karataş K, Baloğlu M. The development and initial tests for the psychometric properties of the COVID-19 Phobia Scale (C19P-S). Pers Individ Dif 2020; 164: 110108

18. Amerikan Psikiyatri Birliği. American Psychiatric Association: Diagnostic and Statistical Manual of Mental Disorders Fifth Edition. Arlington: American Psychiatric Association Publishing. 2013.

19. Kang $L, L i Y, H u S$, Chen $M$, Yang $C$, Yang BX, et al. The mental health of medical workers in Wuhan, China dealing with the 2019 novel coronavirus. Lancet Psychiatry 2020; 7(3): e14.

20. Alenazi TH, BinDhim NF, Alenazi MH, Tamim $H$, Almagrabi RS, Aljohani SM et al. Prevalence and predictors of anxiety among healthcare workers in Saudi Arabia during the COVID-19 pandemic. I Infect Public Health. 2020 Nov;13(11):1645-51.

21. Arora A, Jha AK, Alat P, Das SS. Understanding coronaphobia. Asian I Psychiatr 2020; 54: 102384.

22. Lee $S A$, Jobe $M C$, Mathis AA, Gibbons JA. Incremental validity of coronaphobia: Coronavirus anxiety explains depression, generalized anxiety, and death anxiety. I Anxiety Disord 2020; 74: 102268.

23. Andrade EF, Pereira LJ, Oliveira APL, Orlando DR, Alves DAG, Guilarducci JS, et al. Perceived fear of COVID-19 infection according to sex, age and occupational risk using the Brazilian version of the fear of COVID-19 scale. Death Stud. 2020; $26: 1-10$.

24. Amin F, Sharif S, Saeed R, Durrani N, Jilani D. COVID-19 pandemic- knowledge, perception, anxiety and depression among frontline doctors of Pakistan. BMC Psychiatry 2020; 20(1): 459 .

25. Nguyen $L H$, Drew DA, Joshi AD, Guo CG, Ma W, Mehta $R S$, et al. Risk of COVID-19 among frontline healthcare workers and the general community: a prospective cohort study. medRxiv 2020 .

26. Lu W, Wang H, Lin Y, Li L. Psychological status of medical workforce during the COVID-19 pandemic: a cross-sectional study. Psychiatry Res. 2020; 288: 112936. 
27. Abolfotouh MA, Almutairi AF, BaniMustafa AA, Hussein MA. Perception and attitude of healthcare workers in Saudi Arabia with regard to COVID-19 pandemic and potential associated predictors. BMC Infect Dis 2020; 20(1): 719 .

28. Cabarkapa S, Nadjidai SE, Murgier J, Ng CH. The psychological impact of COVID-19 and other viral epidemics on frontline healthcare workers and ways to address it: A rapid systematic review. Brain Behav Immun Health 2020; 8: 100144.

29. Phua J, Weng L, Ling L, Egi M, Lim CM, Divatia N, et al. Asian Critical Care Clinical Trials Group. Intensive care management of coronavirus disease 2019 (COVID-19): challenges and recommendations. Lancet Respir Med. 2020; 8(5): 506-17.
30. Arrogante O, Aparicio-Zaldivar E. Burnout and health among critical care professionals: The mediational role of resilience. Intensive Crit Care Nurs 2017; 42: 110-5.

31. Kramer V, Papazova I, Thoma A, Kunz M, Falkai P, Schneider-Axmann $T$, et al. Subjective burden and perspectives of German healthcare workers during the COVID-19 pandemic. Eur Arch Psychiatry Clin Neurosci 2020:1-11.

32. Korkmaz S, Kazgan A, Çekiç S, Tartar AS, Balcı HN, Atmaca M. The anxiety levels, quality of sleep and life and problem-solving skills in healthcare workers employed in COVID-19 services. J Clin Neurosci 2020; 80: 131-6. 